\title{
DAMPAK PSIKOLOGIS NARAPIDANA SEUMUR HIDUP DALAM PERUBAHAN PIDANANYA MENJADI PIDANA PERCOBAAN 20 TAHUN
}

\author{
${ }^{1}$ Rico Fitranto, ${ }^{2}$ Mitro Subroto \\ 1,2, Politeknik IImu Permasyarakatan \\ Correspondence author: ricofitranto@gmail.com subrotomitro07@gmail.com
}

Depok, 16514, Indonesia

\begin{abstract}
A prisoner is someone whose rights and freedoms must be revoked because he has committed a crime. The loss of freedom of freedom, and the things that must be faced in the face of the environment and the new, and having to part with loved ones, as well as relatives, which negatively affects actions. This study aims to determine the psychological development with a life sentence against a criminal change into a 20-year probationary sentence. This writing uses a normative approach using library techniques. Many with life sentences experienced despair and lost hope, the change of sentence to 20 years probation was a second chance that was coveted by the people. In serving the sentence, there are three important parts that have a large enough influence on the condition of a psychologist, namely environmental conditions in prisons, characteristics between individuals and social support.
\end{abstract}

\section{Keywords: Life Imprisonment; Prisoners; Psychological Impact}

\begin{abstract}
Abstrak
Narapidana merupakan seseorang yang harus dicabut hak dan kebebasannya karena telah melakukan kejahatan. Hilangnya kebebasan narapidana, dan keharusan untuk menghadapi lingkungan dan budaya baru, serta harus berpisah pula dengan orang yang dicintai seperti keluarga serta kerabat, berakibat menimbulkan emosi negatif kepada narapidana. Penelitian ini bertujuan untuk mengetahui keadaan psikologis narapidana dengan vonis hukuman seumur hidup terhadap perubahan pidananya menjadi pidana percobaan 20 tahun. Penulisan ini memakai metode pendekatan normative dengan menggunakan teknik kepustakaan. Banyak narapidana dengan hukuman seumur hidup mengalami putus asa dan kehilangan harapan, perubahan pidana menjadi pidana percobaan 20 tahun merupakan kesempatan kedua yang didamkan oleh para narapidana. Dalam menjalani hukumannya, ada tiga bagian penting yang cukup besar pengaruhnya kepada keadaan psikologis seorang narapidana yaitu kondisi lingkungan dalam Lapas, karakteristik antar individu dan dukungan sosial.
\end{abstract}

Kata Kunci: Dampak Psikologis; Narapidana; Penjara Seumur Hidup

Open Access at:http://ojs.uho.ac.id/index.php/PUBLICUHO/index

Journal Publicuho is licensed under a Creative Commons Attribution 4.0 International License. 


\section{PENDAHULUAN}

Pemidanaan adalah tindakan yang dilakukan kepada pelaku kejahatan, pemidanaan dimaksudkan bukan dikarenakan seseorang melakukan kejahatan, tetapi bertujuan agar seorang pelaku kejahatan tidak lagi melakukan kejahatan dan kejahatan tersebut tidak dilakukan oleh orang lain.

Menurut Profesor Sudarto, hukuman berasal dari istilah "hukum", dan bisa diartikan sebagai "keputusan hukuman" atau "keputusan hukum".Definisi pemidanaan pada hukum Indonesia ialah proses atau cara penjatuhan hukuman atau sanksi bagi mereka yang melakukan pelanggaran atau tindak pidana. Pemidanaan ialah kata lain dari sebuah penghukuman. (A.,1984).

Berat atau ringannya vonis hukuman yang ditetapkan oleh proses peradilan akan ditenentukan oleh berat atau ringan-nya suatu kejahatan yang dilakukan pelaku kejahatan. Sebagai negara hukum, berbagai macam hukum yang akan dijatuhkan pada pelaku kejahatan telah diatur dalam Peraturan perundang-undangan. Hukum Pidana mengatur tentang Hukum Pidana didalam KUHP. "Hukum Pidana" Pasal tentang Pidana Bab II mengatur bahwa Pasal 10 pidana denda dibagi menjadi pidana pokok dan pidana tambahan. Kejahatan utama adalah penjara, penjara, hukuman mati dan denda. Tindak pidana lainnya adalah pencabutan hak tertentu, perampasan barang tertentu dan penyerahan putusan pengadilan.

Pidana penjara seumur hidup merupakan pidana yang diatur dalam Pasal 12 ayat 1 KUHP, yang menyatakan bahwa "penjara adalah pidana penjara seumur hidup atau jangka waktu. Pasal 12 ayat 4 KUHP mengatur bahwa pidana penjara dalam jangka waktu tertentu paling lama 20 tahun" (Moeljatno, 2009).

Dari penafsiran Pasal 12 ayat 1 KUHP dapat disimpulkan bahwa pidana penjara seumur hidup adalah suatu proses pidana penjara bagi terpidana selama hidupnya sampai mati. Penjara seumur hidup berarti terpidana harus menjalani hukuman, sedangkan hak dan kebebasan hidupnya dibatasi.

Penjara seumur hidup merupakan salah satu bentuk pidana penjara, tentunya pidana penjara berdampak negatif terhadap kondisi narapidana. Barda Nawawi Arief mengemukakan bahwa "pemenjaraan tidak hanya mengakibatkan perampasan kemerdekaan, tetapi juga berdampak negatif terhadap hal-hal yang berkaitan dengan perampasan kemerdekaan itu sendiri".

Kondisi tekanan yang datang dan harus dihadapi sangat mempengaruhi keadaan psikis narapidana bukan hanya saat menerima vonis hukuman, tetapi juga saat kemudian 


\section{Journal Publicuho}

ISSN2621-1351 (online), ISSN 2685-0729 (print)

Volume 4 Number 3 (August - October), (2021) pp. 947-955

Accredited SINTA SK.NOMOR 28/E/KPT/2019

Open Access at:http://ojs.uho.ac.id/index.php/PUBLICUHO/index

$10.35817 / j p u . v 4 i 3.20628$

menjalani masa hukuman di dalam lembaga pemasyarakatan. Tidak menutup kemungkinan bahwa kondisi seperti ini akan membuat narapidana dengan vonis hukuman pidana penjara seumur hidup dapat melakukan perbuatan yang bisa membuat dirinya sendiri dan orang lain berada dalam keadan bahaya.

Selain itu, dapat pula muncul perilaku yang tidak normal dan akan berujung pada percobaan untuk melarikan diri dari dalam penjara, membuat kegaduhan atau memancing keributan antar narapidana, bahkan mungkin melawan petugas di dalam lapas, depresi, putus asa, menyakiti diri sendiri atau self-injury, bahkan mungkin keinginan untuk mengakhiri hidupnya dengan cara bunuh diri.

Rasa putus asa yang dialami, kondisi kritis tidak menyenangkan yang membuat narapidana dengan vonis seumur hidup merasa kehilangan kesempatan untuk dapat memperbaiki keadaan serta untuk berubah menjadi individu yang lebih baik. Perubahan pada pola hidup, lingkungan hidup yang terbatas, dan keadaan tertekan yang dialami oleh para narapidana dengan vonis seumur hidup membuat hidup narapidana penuh dengan tekanan dan perasaan menderita.

Rasa trauma yang diakibatkan oleh penderitaan berkepanjangan yang dialami oleh para narapidana dengan vonis hukuman penjara seumur hidup membutuhkan keterampilan agar mampu bangkit. Perlakuan terhadap narapidana merupakan hal yang sangat kursial. Salah satu faktor faktor penentu keberhasilan dari proses pembinaan narapidana adalah keadaan lingkungan. Hukum bertujuan untuk mengayomi agar visi dari bangsa Indonesia dapat dicapai. Khususnya tentang bagaimana perlakuan yang diberikan kepada seorang narapidana, bukan hanya mengayomi warga negara dari penanggulangan perbuatan jahat oleh terpidana tapi juga agar pelaku kejahatan tersebut mendapatkan pengayoman dengan bimbingan dan pembinaan, secara rohani ataupun jasmani sehingga narapidana bisa kembali ke masyarakat sebagai seorang warga negara yang baik, serta bertanggung jawab dan berguna.

\section{METODOLOGI}

Artikel ini menggunakan penelitian normatif, yaitu hukum dianggap sebagai aturan atau norma. Metode yang digunakan dalam penelitian ini adalah metode penelitian kepustakaan. Literatur atau penelitian kepustakaan dapat diartikan sebagai serangkaian kegiatan yang berkaitan dengan metode pengumpulan data kepustakaan, membaca, mencatat, dan mengolah bahan penelitian. 


\section{HASIL DAN PEMBAHASAN}

Pengertian pelaku dalam Kamus Besar Bahasa Indonesia (KBBI) adalah orang yang sedang menjalani hukuman karena melakukan tindak pidana; divonis. Pada saat yang sama, menurut kamus utama, istilah ilmiah mendefinisikan tahanan sebagai tahanan. Selain itu, dalam kamus hukum penjara, kriminal didefinisikan sebagai orang yang menjalani hukuman di penjara.

Menurut Undang-Undang Nomor 12 Tahun 1995 tentang Lembaga Pemasyarakatan, menurut Pasal 1 ayat 7, penjahat adalah penjahat yang telah menjalani pidana di dalam penjara. Wilson mengatakan, "Tahanan adalah orang-orang bermasalah. Mereka dipisahkan dari masyarakat untuk belajar hidup dengan baik di masyarakat." Pengertian terpidana (Pasal 6, Pasal 1 Undang-Undang Nomor 12 Tahun 1995) sendiri mengacu pada orang yang telah dipidana berdasarkan putusan pengadilan yang bersifat tetap.

\section{a. Pidana Seumur Hidup}

Hukuman seumur hidup pada dasarnya sama dengan hukuman mati, dan merupakan hukuman yang mutlak. Oleh karena itu, pidana penjara seumur hidup masih tergolong pidana penjara tetap karena pelakunya sudah divonis hukuman tertentu, yaitu narapidana akan menjalani hukuman dengan sisa hidupnya walaupun tidak ada yang mengetahui secara pasti sampai kapan naarapidana hidup di dunia ini. Karena ketidakpastian usia narapidana yang dijatuhi hukuman penjara seumur hidup, ada pandangan lain bahwa penjara seumur hidup sebenarnya adalah penjara yang tidak pasti.

Pandangan bahwa pidana penjara seumur hidup dianggap sebagai pidana tidak tetap juga didukung oleh KUHP yang secara jelas tidak mengatur rumusan pembatasan pidana penjara seumur hidup. Pasal 12 KUHP hanya mengatur bahwa pidana penjara paling singkat satu hari dan paling lama lima belas (lima belas) tahun berturut-turut, dan dasar pembatasan waktu tindak pidana adalah minimal (straf minima) dan batas maksimal (straf maxima).

Sistem pidana Indonesia menetapkan bahwa hukuman penjara seumur hidup selalu merupakan alternatif dari hukuman mati, dan selalu merupakan alternatif dari hukuman penjara hingga paling lama dua puluh tahun (Waluyo, 2008). Sebagai alternatif dari pidana mati, pidana seumur hidup semacam ini juga berkaitan dengan fungsi pembantu, yaitu alternatif (pengganti) bagi tindak pidana yang dapat diancam dengan pidana mati yang paling tinggi. Pidana penjara seumur hidup merupakan jenis sanksi pidana yang dapat dipilih untuk dieksekusi.

Hukuman atas kejahatan merupakan kebutuhan mutlak, bukan hanya untuk dijatuhkan, tetapi juga harus dilakukan. Sifat sebenarnya dari hukuman adalah balas dendam. Dasar pembelaan pidana termasuk dalam klasifikasi imperatif, yang mensyaratkan bahwa setiap 


\section{Journal Publicuho}

ISSN2621-1351 (online), ISSN 2685-0729 (print)

Volume 4 Number 3 (August - October), (2021) pp. 947-955

Accredited SINTA SK.NOMOR 28/E/KPT/2019

Open Access at:http://ojs.uho.ac.id/index.php/PUBLICUHO/index

10.35817/jpu.v4i3.20628

pelanggaran hukum harus dibalas. Penting untuk menegakkan hukum secara tidak memihak dan membalas sesuai dengan hukum. Keharusan berdasarkan keadilan dan hukum mutlak diperlukan, sehingga setiap pengecualian atau pembatasan yang semata-mata didasarkan pada tujuan harus dikesampingkan.

Selain menggunakan teori balas dendam sebagai tujuan melakukan hukuman atas kejahatan, hukum juga menginginkan cermin keadilan. Oleh karena itu, penjatuhan hukuman bukan hanya alat untuk balas dendam, tetapi juga untuk hukum yang menuntut keadilan. Jadi itu berarti bahwa hukuman atas kejahatan adalah untuk membuat orang merasakan keadilan.

Santoso (2013: 49) menunjukkan bahwa penelitian psikologi memiliki empat arah yang berbeda untuk menyelidiki hubungan antara kepribadian dan kejahatan. Pertama, pertimbangkan perbedaan dalam struktur kepribadian penjahat, bukan jenis kejahatan yang mereka lakukan; kedua, prediksi perilaku; ketiga, periksa sejauh mana dinamika kepribadian normal berperan dalam penjahat; keempat, coba kuantifikasi penjahat Perbedaan individu antar jenis dan kelompok.

\section{b. Pergantian Hukuman Dengan Masa Percobaan}

Pidana penjara seumur hayati adalah galat satu menurut 2 jenis pidana penjara pada Indonesia yg diatur pada Pasal 12 ayat 1 kitab undang-undang hukum pidana yg mengatur bahwa pidana penjara merupakan pidana penjara seumur hayati atau jangka saat eksklusif. Pasal 12 ayat 4 kitab undang-undang hukum pidana mengatur bahwa pidana penjara pada jangka saat eksklusif nir boleh lebih menurut 20 tahun.

Menurut Pasal 12 kitab undang-undang hukum pidana, ketentuan generik mengenai pidana penjara seumur hayati sebenarnya hanya mempunyai satu ketentuan, yaitu ayat (1). Melalui peraturan tadi bisa diketahui adanya jangka saat eksklusif bagi peraturan pidana penjara.

Ketentuan Pasal 12 ayat 1 kitab undang-undang hukum pidana sebenarnya hanya memberitahuakn bahwa bentuk pidana penjara yg sebenarnya umumnya merupakan pidana penjara seumur hayati \& pidana penjara sementara. Oleh lantaran itu, pada anggaran generik ini nir disebutkan bagaimana mengatur mengenai ketentuan pidana penjara seumur hayati, misalnya halnya ketentuan pidana penjara buat jangka saat eksklusif. Sementara itu, herbi divestasi bersyarat, dalam Pasal 15 kitab undang-undang hukum pidana pula diatur mengenai adanya kemungkinan dalam narapidana seumur hayati buat memperoleh divestasi bersyarat. Ketentuan Pasal 15 kitab undang-undang hukum pidana secara rinci mengungkapkan:

1) Jika terpidana telah menjalani dua per tiga dari lamanya pidana penjara yang dijatuhkan kepadanya, yang sekurangkurangnya harus Sembilan bulan, maka 
kepadanya dapat diberikan pelepasan bersyarat. Jika terpidana harus menjalani beberapa pidana berturut-turut, pidana itu dianggap sebagai satu pidana.

2) Dalam memberikan pelepasan bersyarat, ditentukan pula suatu masa percobaan, serta ditetapkan syaratsyarat yang harus dipenuhi selama masa percobaan.

3) Masa percobaan itu lamanya sama dengan sisa waktu pidana penjara yang belum dijalani, ditambah satu tahun. Jika terpidana ada dalam tahanan yang sah, maka waktu itu tidak termasuk masa percobaan.

Sedangkan penjelasan yang tertuang dalam pasal pasal di RKUHP, menyebutkan : Pasal 69 (1) Jika narapidana yang menjalani pidana penjara seumur hidup telah menjalani pidana penjara paling singkat 15 (lima belas) tahun, pidana penjara seumur hidup dapat diubah menjadi pidana penjara 20 (dua puluh) tahun dengan Keputusan Presiden setelah mendapatkan pertimbangan Mahkamah Agung.

(2) Ketentuan mengenai tata cara perubahan pidana penjara seumur hidup menjadi pidana penjara 20 (dua puluh) tahun sebagaimana dimaksud pada ayat (1) diatur dengan Peraturan Pemerintah."

Pasal 73

(1) Syarat yang harus dipenuhi selama masa percobaan sebagaimana dimaksud dalam Pasal 72 ayat (3) terdiri atas:

a) Syarat umum berupa narapidana tidak akan melakukan Tindak Pidana; dan

b) Syarat khusus berupa narapidana harus melakukan atau tidak melakukan perbuatan tertentu, tanpa mengurangi kemerdekaan beragama dan berpolitik, kecuali ditentukan lain oleh hakim.

(2) Syarat khusus sebagaimana dimaksud pada ayat (1) huruf b dapat diubah, dihapus, atau diadakan syarat baru yang semata-mata bertujuan untuk pembimbingan narapidana.

(3) Narapidana yang melanggar syarat sebagaimana dimaksud pada ayat (1) dapat dicabut pembebasan bersyaratnya.

(4) Pembebasan bersyarat sebagaimana dimaksud pada ayat (3) tidak dapat dicabut setelah melampaui 3 (tiga) Bulan terhitung sejak saat habisnya masa percobaan kecuali dalam waktu 3 (tiga) Bulan terhitung sejak habisnya masa percobaan narapidana dituntut karena melakukan Tindak Pidana yang dilakukan dalam masa percobaan.

(5) Dalam hal narapidana sebagaimana dimaksud pada ayat (4) dijatuhi pidana penjara untuk waktu tertentu atau pidana denda paling sedikit kategori III, pembebasan bersyarat dicabut.

Dalam Peraturan Pemerintah Republik Indonesia Nomor 28 Tahun 2006 masih terdapat perubahan klausula pengecualian yaitu perbuatan baik dan pidana penjara lebih dari 6 (enam) bulan. Peraturan tersebut juga memiliki ketentuan khusus. Menurut alinea ketiga Pasal 34, "Bagi pelaku tindak pidana terorisme, narkotika, psikotropika, korupsi, kejahatan 


\section{Journal Publicuho}

ISSN2621-1351 (online), ISSN 2685-0729 (print)

Volume 4 Number 3 (August - October), (2021) pp. 947-955

Accredited SINTA SK.NOMOR 28/E/KPT/2019

Open Access at:http://ojs.uho.ac.id/index.php/PUBLICUHO/index

$10.35817 / j p u . v 4 i 3.20628$

terhadap keamanan nasional, kejahatan berat hak asasi manusia, dan kejahatan terorganisir lintas batas lainnya, hukuman diringankan jika memenuhi syarat-syaratnya. Yaitu, berkelakuan baik \& Telah menjalani 1/3 (sepertiga) dari hukumannya."

Akhirnya, setelah berkonsultasi dengan direktur penjara, pelaku kejahatan tertentu akan menerima pengurangan hukuman sesuai dengan Pasal 34 ayat (3). Keputusan tersebut diberikan melalui keputusan menteri. Ketentuan-ketentuan tersebut di atas kemudian bertentangan dengan syarat-syarat pengurangan hukuman penjara seumur hidup, dan status mereka berubah menjadi hukuman percobaan. Namun peraturan tersebut di atas tidak menghapus ketentuan peraturan tentang syarat memperoleh keringanan, peraturan tersebut kemudian mengatur pembebasan bagi pelaku pidana penjara seumur hidup, dan statusnya diubah menjadi pidana penangguhan dan keringanan tambahan. Agar ketentuan tersebut tidak bertentangan dengan ketentuan persyaratan pengecualian

\section{c. Keadaan Psikologis Narapidana}

Kata psikologi berasal dari bahasa Yunani kuno, kata psyche berarti jiwa (roh), dan logos berarti pengetahuan. Oleh karena itu, dari segi etimologi, psikologi dapat diartikan sebagai ilmu jiwa atau ilmu jiwa. (Walgito, 2002) Secara umum, keadaan mental adalah keadaan atau situasi yang berubungan dengan kejiwaan. Keadaan mental juga dapat digambarkan sebagai suatu keadaan yang ada pada diri individu, yang dapat mempengaruhi sikap dan perilaku individu tersebut. Keadaan mental dapat dijelaskan sebagai keadaan mental yang tidak terlihat dengan mata telanjang, yang merupakan dasar dari perilaku sadar seseorang. Keadaan mental ini adalah dasar dari kepribadian pribadi. (Komalasari, 2017)

Dalam hal ini pidana penjara seumur hidup merupakan bentuk pidana penjara. Tekanan yang dialami narapidana memiliki dampak besar pada kesehatan mental narapidana. Situasi seperti ini dapat menyebabkan narapidana yang dijatuhi hukuman penjara seumur hidup melakukan perbuatan yang dapat merugikan diri sendiri atau orang lain..

Mengenai perasaan, Strens, seperti dikutip Dwi Prasetia danarjati, Murtiadi, dan Ari Ratna Ekawati, (Komalasari, 2017) membagi perasaan menjadi tiga kelompok, yaitu:

a) kehadiran yang berkaitan dengan situasi saat ini yang mereka hadapi. Hal ini terkait dengan situasi saat ini.

b) Perasaan tergesa-gesa maju, bergegas maju dalam peristiwa-peristiwa yang akan datang agar masih ada harapan.

c) Perasaan yang berhubungan dengan masa lalu atau melihat kembali apa yang terjadi. Terjadinya stres tergantung dari sumber stres dan respon seseorang terhadap sumber stres tersebut. Stresor yang dijelaskan oleh (Siswanto, 2010) dipengaruhi oleh lingkungan fisik. Keterbatasan ruang untuk aktivitas pribadi dapat menyebabkan stres. Pembatasan 
kebebasan bergerak dan hilangnya privasi pribadi adalah tekanan harian yang dihadapi tahanan. Kondisi lingkungan di dalam Lapas akan menyebabkan setiap narapidana memiliki pandangan yang berbeda-beda. Lapas sendiri juga berusaha membekali narapidana dengan berbagai materi penyucian spiritual dan kegiatan aktif lainnya, dengan harapan narapidana memiliki kemampuan manajemen emosi yang baik. Lembaga pemasyarakatan yang memenuhi standar dan memperhatikan kondisi kehidupan narapidana dapat menghindari tekanan narapidana selama menjalani hukuman. Meskipun demikian, tekanan masih ada di antara tahanan, dan tingkat bunuh diri bagi tahanan berakibat fatal.

Stres bisa menimpa siapa saja, tanpa memandang jenis kelamin. Pembatasan kebebasan bergerak dan hilangnya privasi pribadi adalah tekanan harian yang dihadapi tahanan. Adanya sumber stres yang sedemikian kuat di dalam lapas dapat menyebabkan narapidana merasa stres. Cervon dan Pervin, 2012)menunjukkan bahwa stres dianggap sebagai suatu peristiwa, ketika seseorang melihat situasi dan kondisi sebagai stres atau di luar kemampuannya dan dapat membahayakan kesehatannya. Sumber stres disebut stresor.

\section{KESIMPULAN}

Dalam sistem pidana Indonesia, pidana penjara seumur hidup selalu merupakan pengganti (pengganti) pidana mati, dan selalu merupakan pengganti pidana penjara dua puluh tahun. Sebagai alternatif dari pidana mati, pidana penjara seumur hidup juga mengacu pada fungsi pembantu, yaitu menggantikan (mengganti) kejahatan yang diancam dengan pidana mati yang paling tinggi. Pidana penjara seumur hidup merupakan sanksi pidana yang dapat dijatuhkan.

Penjara seumur hidup sebagai salah satu jenis pidana penjara akan menimbulkan sederet penderitaan, tidak hanya narapidana yang bersangkutan yang merasakannya, tetapi juga orang-orang yang hidupnya bergantung pada terpidana yang bersangkutan. Penjara seumur hidup tidak hanya akan membawa rantai penderitaan seumur hidup bagi para narapidana, tetapi juga membawa penderitaan bagi mereka yang bergantung pada para narapidana ini untuk hidup mereka.

Setiap persidangan dalam keadaan sulit dan berfluktuasi karena lingkungan dan ruang untuk mencari solusi sendiri dipidana dengan pidana penjara dan pidana kurungan tetap apabila menghadapi tekanan dan masalah. Keadaan tahanan.

Hukuman diubah menjadi 20 tahun masa percobaan, membawa angin segar bagi para tahanan yang telah putus asa dan mengakui kejahatan mereka dan masuk penjara. Karena secara filosofis koreksi merupakan sistem yang jauh dari definisi-definisi lama tentang hukuman, seperti filosofi punishment, deterrence, dan rehabilitasi. Sistem penjara mengikuti konsep reintegrasi ke dalam masyarakat, dengan asumsi bahwa kejahatan merupakan konflik antara pelaku dan masyarakat, sehingga pemidanaan bertujuan untuk memulihkan 


\section{Journal Publicuho}

ISSN2621-1351 (online), ISSN 2685-0729 (print)

Volume 4 Number 3 (August - October), (2021) pp. 947-955

Accredited SINTA SK.NOMOR 28/E/KPT/2019

Open Access at:http://ojs.uho.ac.id/index.php/PUBLICUHO/index $10.35817 / j p u . v 4 i 3.20628$

konflik yang timbul dari penyatuan kembali pelaku dan masyarakat (reintegrasi ke masyarakat). Dengan demikian, negara berusaha menempatkan seseorang dalam suasana yang mendorong perilaku positif. Di sisi lain, orang berusaha mencegah seseorang menghubungi proses sosialisasi budaya penjara dengan mengubah hukumannya.

\section{REFERENSI}

Barda Nawawi Arief, 1994, Kebijakan Legislatif dalam Penanggulangan Kejahatan

Dengan Pidana Penjara, Universitas Diponegoro, Semarang. Bambang, Waluyo . (2008). Pidana dan Pemidanaan. Jakarta : Sinar Grafika. Moeljatno. (2009). Kitab UndangUndang Hukum Pidana. Jakarta: Bumi Aksara. Santoso, T., Zulfa, A, E. (2013). Kriminologi. Jakarta: Rajagrapindo Persada.

Soekanto, S., Liklikuwata, H., \& Kusumah, W, M., (1981). Kriminologi Suatu Pengantar.

Jakarta: Ghalia Indonesia.

Muladi. (1996). Kapita Seleksi Hukum Pidana, Badan Penerbit Universitas Diponegoro, Semarang. 